\title{
RUANG-RUANG KEADILAN BAGI SANG MARGIN
}

\author{
Danang Kurniawan \\ Hatford Seminary \\ dekalogy@gmail.com
}

\begin{abstract}
This essay examines just space(s) from the perspective of Christian hospitality towards the marginalized. The focus for Letty Russell in her theology addresses those considered the 'unfortunate' or those victimized by the variegated visage of injustice (the 'unfair') as that face is set against 'the outsiders'; Miroslav Volf focuses on the 'other,' as does Amos Yong concerning "the stranger." Nevertheless, they use these three terms interchangeably. To build just space(s) for the marginalized, I intend to approach the justice discourse via two arguments: first, by claiming that every theory of justice derived philosophically tends to get trapped in matters of techno-calculation; second, by proposing the relevance of a theological approach for "patching" such philosophical shortcomings. Following the parable of the workers in the vineyard in Matthew 20:10-16, we see that a theological approach yields a conceptualization of generosity - as the commentaries of Michael Green show-thereby demonstrating the relevance of such theological praxis. As a study in Christian hospitality, this essay proposes several ethical tenets for the building of just space(s) as spaces for justice that take as their point of departure the very same marginalized toward whom these spaces are oriented.
\end{abstract}

Keywords: just space, injustice, the marginalized, parable of the workers in the vineyard, generosity, hospitality

\begin{abstract}
Abstrak
Artikel ini akan mendiskusikan konsep ruang keadilan dari perspektif hospitalitas kristiani bagi kaum yang marginal. Letty Russel lebih memfokuskan teologinya, menyebut mereka yang tidak beruntung (unfortunate) atau korban beragam wajah ketidakadilan (unfair), pada yang tersisih (the outsider), Miroslav Volf lebih fokus pada sang liyan (the other), dan Amos Yong pada "yang asing" (the stranger). Meski demikian, mereka memakai ketiga istilah itu secara bergantian. Demi membangun ruang keadilan bagi yang
\end{abstract}


termarginalkan, saya ingin mendekati diskursus keadilan dengan dua argumentasi. Pertama, setiap teori tentang keadilan secara filosofis cenderung terjebak pada debat kalkulasi-teknisnya. Kedua, pendekatan teologis dengan demikian relevan untuk "menambal" kekurangan pendekatan filosofis tersebut. Melalui kisah perumpamaan para pekerja di kebun anggur dalam Matius 20:1-16, pendekatan teologis yang menawarkan konsep kemurah-hatian (generosity)—seperti dalam tafsir Michael Green-memperlihatkan secara teologis relevansi praksisnya. Dalam kajian hospitalitas kristiani, tulisan ini mengusulkan beberapa prinsip etis dalam membangun ruang keadilan: ruang keadilan yang berangkat dari, dan berorientasi kepada, mereka yang marginal.

Kata-kata Kunci: ruang keadilan, ketidakadilan, sang margin, perumpamaan pekerja di kebun anggur, kemurah-hatian, hospitalitas

\section{Pendahuluan:}

\section{Sekat Ruang antara Adil dan Tidak Adil}

Jika kehidupan kita sebagai manusia diibaratkan hidup di dalam sebuah ruangan atau gedung, terdapat sekat tebal yang "memaksa" kita hidup terpisah dalam dunia adil dan tidak adil. Dalam bukunya Justice in an Unjust World, Karen Lebacqz memulai refleksinya tentang dunia adil dan tidak adil melalui sebuah analogi polarisasi dua habitat: habitat para burung dan para ikan. Menurut Lebacqs, orang-orang yang hidup di "udara," ruang hidup para burung, bergerak lebih cepat karena ringan terbang di angkasa. Sementara di ruang terpisah, mereka yang hidup di "laut," para ikan, berenang lambat menghadapi lautan hutang demi membayar beban sewa rumah, listrik, pendidikan, dan kebutuhan hidup lainnya. ${ }^{1}$ Lebacqs menyebut bahwa para burung dapat menjadi para penindas; pelaku ketidakadilan. Kelompok penindas tidaklah jahat pada dirinya sendiri, melainkan bertindak didorong oleh naluri alami untuk menyintas dengan sukses. Mereka sukses karena dukungan sistem peradaban dalam bidang politik, pendidikan, dan ekonomi. Sayangnya, mereka kurang peka terhadap kelompok yang "termarginalkan" oleh sistem tersebut. Kelompok yang diuntungkan oleh sistem tersebut, meminjam istilah Elisabeth T. Vasko, disebut sebagai "saksi-saksi yang apatis" (bystanders). ${ }^{2}$

${ }^{1}$ Karen Lebacqz, Justice in an Unjust World: Foundations for a Christian Approach to Justice (Minneapolis, MN: Fortress Press, 2007), 10-11.

2 Lihat Elisabeth T Vasko, Beyond Apathy: A Theology for Bystanders (Minneapolis, MN: Fortress Press, 2015), 12, 70. Vasko menulis buku Beyond Apathy sebagai undangan kepada kaum kulit putih di Amerika untuk menyadari bahwa peradaban Amerika telah dibangun di atas penderitaan para budak, terutama kulit hitam. Tanpa menyalahkan para penikmat keuntungan dari 
Kelompok penindas tersebut cenderung, baik sengaja maupun tidak, melanggengkan dikotomi identitas manusia dalam etnis, gender, tingkat ekonomi, dan situasi politik. Lebih lanjut, dikotomi tersebut menciptakan simpul-simpul kuat dari ketidakdilan (web of injustice) yang hampir mustahil dilawan. ${ }^{3}$

Lebacqs mencontohkan perbudakan yang dilakukan oleh orang-orang kulit putih terhadap orang-orang berkulit hitam, penyiksaan dan perkosaan terhadap perempuan, seakan terjadi begitu saja sebagi akibat dikotomi realitas akan yang lemah dan yang kuat. Sebagaimana kita bangun dan menghirup udara, ketidakadilan memang sedemikian merasuki tubuh dan dunia kita dan menggiring intuisi rasional makhluk hidup untuk bertahan (proharesis) semata. ${ }^{4}$ Pendek kata, Lebacqs menyingkap fakta akan perbedaan-perbedaan identitas yang telah melahirkan sekat ruang yang membutakan kelompok penindas untuk melihat realitas ketidakadilan dalam masyarakat. Refleksi terhadap adanya ruang adil dan tidak adil tersebut menyadarkan Lebacqs untuk melihat dirinya sebagai bagian dari para burung dengan kemewahan terberi: berkulit putih, berpendidikan tinggi, tinggal di rumah yang pantas, dan seterusnya. Kesadaran akan sekat antara ruang adil dan tidak adil menginspirasi Lebacs pertama-tama untuk bersikap kritis terhadap pelaku ketidakadilan; lalu berbela rasa kepada para korban ketidakadilan: yang marginal.

Dengan fakta kokohnya sekat ruang adil-tidak adil di atas, mungkinkah membangun ruang keadilan bagi yang marginal? Diskursus etika seperti apa yang bisa menyediakan solusi bagi mereka? Lebih jauh, apakah kita memiliki akar tradisi teologis yang menolong kita untuk menciptakan ruang-ruang keadilan baik secara imajiner maupun secara konkret? Berikut saya mengajak kita melihat ruang-ruang terminologi yang dapat menolong kita untuk memahami peliknya persoalan ketidakadilan dan mengusulkan sebuah ide dari tradisi kristiani, yaitu hospitalitas

kemakmuran yang ada, Vasko ingin membuka mata kaum kulit putih bahwa peradaban Amerika adalah ibarat gelas pecah yang memang masih mungkin dibangun ulang. Pertama-tama dengan kesadaran bahwa luka-luka para kulit hitam yang diakibatkan rasisme di masa lalu, yang juga masih berlangsung, harus dihentikan, dan perlu dirawat dengan lebih baik. Narasi tersebut dimaksudkan Vasko untuk mengundang orang-orang kulit putih sebagai para saksi yang tidak bersembunyi dari "dosa sejarah", melainkan berbelas kasih (compassion), dan aktif mengupayakan rekonsiliasi dengan menempatkan orang-orang kulit hitam sebagai kelompok setara dalam perlakuan keadilan. Kaum kulit putih diajak untuk berpikir dan bertindak melampaui apatisme (beyond apathy).

3 Ibid., 10-36.

4 Proharesis (violition) merupakan salah satu istilah terpenting dalam filsafat Epictetus untuk menggambarkan kehendak manusia yang didasarkan pada pengertian, kemauan, dan kebutuhan diri sendiri tanpa mempertimbangkan konsekuensi yang diderita pihak lain. Lihat Margaret Graver, "Epictetus," Stanford Encyclopedia of Philosophy, 2017, https://plato.stanford.edu/entries/epictetus/. 
(keramahtamahan), untuk menjawab persoalan ketidakadilan tersebut.

Dalam kajian hospitalitas kristiani, tulisan ini mengusulkan beberapa prinsip etis dalam membangun ruang keadilan: ruang keadilan yang berangkat dari, dan berorientasi kepada mereka yang marginal. Untuk keperluan pembaca, pertama, saya akan menyajikan fakta ruang adil dan tidak adil dalam hidup kolektif masyarakat. Kedua, saya akan menjelaskan secara sangat singkat dinamika ruang teoretis yang tidak pernah selesai mengenai, baik definisi maupun jalan keluar untuk menolong, para korban ketidakadilan. Alhasil, dari perdebatan-perdebatan teoretis itu, mereka, sebagai individu/golongan yang termarginalkan, seolah tidak dapat keluar dari ruang pengap ketidakadilan karena belenggu kalkulasi-kalkulasi yang hendak diterapkan, baik oleh negara maupun masyarakat. Hal ini disebabkan karena variabel konteks dari ruang-ruang keadilan yang dibangun tidak pernah seragam sehingga memerlukan kalkulasi-kalkulasi yang terus bergerak. Sayangnya, seperti yang saya ingin tunjukkan melalui artikel ini, prinsip-prinsip itu kemudian bukan hanya bertentangan satu sama lain, melainkan juga tidak menyentuh para korban ketidakadilan yang dimarginalkan.

Ketiga, prinsip-prinsip etis yang muncul dari pendekatan filosofis lebih banyak berbicara tentang teknis, namun kurang memberi ruang bagi sumber penting dari prinsip keadilan, yaitu belas kasih, kemurahan-hati, dan perasaan untuk hidup bersama sebagai masyarakat kolektif umat Allah. Prinsip ini hanya lahir dari rahim sumber keutamaan, teologi. Oleh karena itu, keempat, melalui perumpamaan para pekerja di kebun anggur, saya memformulasikan sebuah narasi kemurah-hatian (generosity) untuk mendemonstrasikan bagaimana ajaran Yesus, sebagai narasi keramahtamahan kristiani mengusulkan konsep keadilan kepada yang marginal. Terakhir, melalui pemikiran para teolog, Russell, Yong, dan Volf, saya ingin memperdalam prinsip hospitalitas itu sebagai desain dalam mengupayakan pembangunan ruang-ruang keadilan bagi yang marginal yang dapat dibaca sebagai ruang imaginasi keadilan secara teologis.

\section{Dinamika Ruang Teoretis: Adakah S[u]atu Keadilan bagi Semua?}

Ruang keadilan dalam ranah teoretis ternyata, baik desain maupun wujudnya, mengalami proses yang kompleks bahkan semenjak filsafat manusia dimulai. Diskusinya tidak pernah dapat menghindar dari kalkulasi-kalkulasi kuantitatif-kualitatif pembagian sumber daya. Debat antara Socrates dan Thrasymacos barangkali merupakan salah satu yang tertua tentang hal ini. Socrates mendefinisikan keadilan dengan menitikberatkan nilai kejujuran dan keutamaan (virtue) dari hidup, sementara Thrasymacos lebih 
mempertimbangkan hasil keuntungan secara komoditas, sebuah praktik yang dapat dibuktikan secara sahih dalam hitungan matematis. ${ }^{5} \quad$ Bagi Thrasymacos, adil pasti menghasilkan keuntungan terbanyak, dan tidak adil hanya akan merugikan. ${ }^{6}$ Baginya, adil adalah sesuatu yang mungkin diperebutkan, dan akan dimenangkan oleh yang kuat. Keadilan dalam percakapan tersebut tidak menjumpai titik temu sebab yang satu cenderung membicarakan keadilan yang bersifat kuantitatif, sedangkan yang lain membicarakan persyaratan kualitatif.

Jika Thrasymacos merujuk keadilan sebagai identik dengan kapasitas pikiran dan tindakan dari "orang kuat" untuk mendatangkan hasil yang menguntungkan dirinya (materi dan kekuasaan), Socrates membantah referensi tersebut dengan mengatakan bahwa orang kuat adalah mereka yang sudah dapat menyatukan fungsi tubuh dan jiwa dalam dirinya sendiri. Keduanya mendambakan sebuah keadilan, namun tidak menemukan sebuah konsensus tentang keadilan. Dari debat tersebut, kita sadar bahwa keadilan memang tidak pernah tunggal. Persoalan adil secara filosofis tidak pernah rampung karena faktor-faktor ini: realitas ragam budaya, tradisi, konteks yang berlaku, dan nilai-nilai lokal di dalamnya.

Budaya dan tradisi menyumbangkan ide tentang bentuk dan esensi ruang definisi keadilan. Alasdair MacIntyre, dalam buku Whose Justice? Which Rationality bertutur, "Sebuah tradisi, seiring masa tertentu, merupakan kancah meluasnya kesepakatankesepakatan tertentu yang telah terdefinisi, namun juga terus didefinisikan ulang, baik dalam debat internal maupun eksternal." "7 Pertanyaan klasik ala pascamodern kemudian muncul, "Siapa pemilik keadilan, dan dengan metode manakah keadilan tersebut dapat dilacak?" Dengan kata lain, keadilan menjadi kabur karena tabiat subjektif dan teoretisnya. Tiga catatan McIntyre tentang keadilan menjadi penting di sini: (1) keadilan dalam ruang ide manusia tidak pernah bebas nilai (subjective-perception); (2) ruang keadilan selalu merepresentasikan "gaya arsitektur" dari tradisitradisi yang berkontestasi dalam pembangunannya; dan (3) dalam argumen-ilmiah (scientific) demi validitas dan universalitasnya definisi keadilan itu sendiri, dengan upaya sekeras apa-pun, definisidefinisi tersebut tak dapat dilepaskan dari inkonsistensi filosofisnya (philosophical inconsistence). ${ }^{8}$ Pendek kata, dalam ruang definisi teoretis dan ruang praksisnya, keadilan memang tidak pernah menemui titik

5 Franz Magnis-Suseno, 13 Tokoh Etika Abad Ke 20 (Yogyakarta: Kanisius, 2000), 15-38.

${ }^{6}$ Ibid., 20.

${ }^{7}$ Alasdair C Macintyre, Whose Justice? Which Rationality? (Notre Dame, IN: University of Notre Dame Press, 1988), 12.

${ }^{8}$ Ibid. 
final, ia tidak pernah absolut. Fakta tersebut didemonstrasikan oleh Miroslav Volf.

Dalam Exclusion and Embrace, Volf membenarkan bukti valid dari argumentasi MacIntyre dalam ruang praksis.' Volf mendemonstrasikan polemik adil-tidak adil melalui kontroversi tradisi Sati di India. Jenderal Charles Napier, yang menjajah India pada tahun 1843, mengutuk tradisi Sati, sebuah ritual pembakaran para perempuan dalam pemakaman para suami mereka. ${ }^{10}$ Bagi Napier, pertimbangan bahwa ritual tersebut merupakan lambang kesetiaan serta pengakuan kepemilikan laki-laki terhadap para istri, adalah omong kosong belaka. Kemudian tanpa segan ia mengeluarkan surat edaran yang berisi hukuman gantung kepada mereka yang masih mempraktikkannya. Menurut Napier, budaya ini tidak berbudaya (beradab) secara rasional. Napier menegasi keyakinan agama dan budaya setempat secara total sehingga terjadi konfrontasi dengan penduduk lokal. Volf menyebut konfrontasi tersebut sebagai "budaya melawan budaya (culture against culture) yang berbuah kekerasan." ${ }^{11}$ Melalui testimoni tersebut, Volf ingin mengingatkan pembacanya bahwa sang Jendral juga telah berlaku tidak adil dengan datang dan menjajah daratan itu. Terlepas dari esensi dari ritual Sati kala itu, kita perlu mencatat bahwa selalu ada ruang gelap (blind space) bagi para pelaku ketidakadilan sehingga mereka rabun untuk melihat tabiat jahat dalam diri mereka. Sebagai hasil, mereka berlaku tidak adil kepada sang liyan. Singkat kata, Volf mengonfirmasi pendapat MacIntyre tentang betapa ruang praksis tentang keadilan sangat dipengaruhi oleh perspektif akan ruang keadilan teoretis dan faktor budaya yang saling berkonstelasi. ${ }^{12}$

Konstelasi tersebut dikatalisasi oleh dua faktor. Pertama, bahwa standar peradaban, kepercayaan, dan nilai keadilan terikat dengan ruang waktu tertentu. Kedua, selalu ada superioritas dan inferioritas dari sebuah kebudayaan (culture) tertentu yang sangat berpotensi memicu klaim kebenaran sepihak. ${ }^{13}$ Faktor-faktor tersebut membentuk versi keadilan yang beragam dan dinamis sehingga tercipta banyak ragam konsep keadilan (many names many justices). Adil bagi pihak yang satu belum tentu adil bagi pihak yang lain. Fakta tersebut diungkapkan oleh Michel Focault, dikutip oleh Volf, bahwa "keadilan seperti halnya kebenaran, merupakan sebuah persoalan dunia....sebagai produk dari banyak versi dari

9 Miroslav Volf, Exclusion and Embrace: A Theological Exploration of Identity, Otherness, and Reconciliation (Nashville, TN: Abingdon Press, 1996), 193231.

10 Asal usul dan polemik tentang tradisi Sati juga dapat ditemukan dalam karya Gavin D'Costa, Theology in the Public Square: Church, Academy, and Nation, Theology in the Public Square: Church, Academy, and Nation (Malden, MA: Blackwell Publishing, 2008), 148-176.

11 Volf, Exclusion and Embrace, 194.

12 Ibid., 197.

${ }^{13}$ Ibid., 193-194. 
ketegangan [...] Versi keadilan tidak pernah absolut dan selalu terikat [ruang] konteks di mana ia lahir, sehingga [seseorang] membutuhkan kehati-hatian untuk menyelidikinya." ${ }^{14}$ Sejalan dengan Volf,persoalan keadilan tidak dapat dilepaskan dari wilayah yang tumpang-tindih dan komitmen mendasar dari para ahli etika. ${ }^{15}$ Menyikapi berbagai pendapat tentang rumitnya keadilan tersebut, bagi Volf, satu-satunya kemungkinan yang masih valid untuk mewujudkan keadilan adalah dengan merangkul (embrace) mereka yang hidup dalam ketidakadilan; mereka, sang liyan yang tertindas, terpinggirkan, dan menderita harus dirangkul masuk pada ruang keadilan dengan prinsip kasih. Prinsip semacam ini lahir dari rahim pemikiran teologis.

\section{Karen Lebacqs: Enam Teori Keadilan dan Sang Margin}

Setahun pascapenerbitan buku Justice in Unjust World tahun 1985, Karen Lebacqs menerbitkan buku Six Theories of Justice yang menjelaskan definisi-definisi keadilan melalui perumpamaan para orang buta yang mendefinisikan seekor gajah menurut masingmasing bagian yang mereka pegang. ${ }^{16}$ Dari perumpamaan tersebut, setiap teori keadilan tidak pernah memadai untuk menjawab semua persoalan ketidakadilan, sebagaimana setiap orang buta tidak mungkin menggambarkan gajah secara utuh. Dengan kata lain, teori-teori keadilan selalu menekankan satu hal, dan oleh karenanya lemah dalam hal lain. Dengan demikian, sebuah teori tentang keadilan selalu parsial, kasuistik, dan terikat zamannya.

Lebacqs "menguji" enam teori keadilan yang mendiskusikan persoalan sosial, ekonomi, teologi, dan filsafat, dan sampai pada kesimpulan bahwa setiap teori memiliki kelemahannya (lihat analogi orang buta memegang gajah). Menurut Lebacqs, secara umum, pendekatan filsafat, ekonomi, dan sosial terjebak pada keadilan kalkulatif-kuantitatif. Sementara, pendekatan teologis, menurut Lebaqcs, lemah secara aplikatif. ${ }^{17}$

Menurut Lebacqs, teori keadilan secara utilitarian dalam pandangan John Stuart Mill hanya menekankan hasil dan luput melihat standar moral dan kebenaran pada proses perwujudannya. ${ }^{18}$ Hal ini disebabkan karena utilitarinisme menitikberatkan pada hasil, kebahagiaan terbesar (greatest good) bagi sebanyak mungkin orang, yang sayangnya berkonsekuensi akan mengorbankan prosesnya. ${ }^{19}$ Selain itu, hak-hak manusiawi yang tidak termasuk dalam sasaran

${ }^{14}$ Ibid.

15 Ibid., 211.

${ }^{16}$ Karen Lebacqz, Six Theories of Justice: Perspectives from Philosophical and Theological Ethics (Minneapolis, MN: Augsburg Publishing House, 1986), 9-14.

17 Untuk memahami argumen Lebacqs tersebut, lih. Lebacqs, Six Theories of Justice, bab 1.

18 Ibid., 21.

${ }^{19}$ Ibid., 21. 
keadilan semacam ini berpotensi diabaikan. Kaum marginal, minoritas, lemah, dan yang tidak berdaya dalam sebuah sistem, akan tetap berada di pinggir. Mereka ibarat tumbal dari kesejahteraan bagi kaum yang lebih dominan; terlebih lagi, kaum yang pertama, dikeluarkan dari lingkaran keadilan.

Lebacqs kemudian menganalisis konsep keadilan Mill berdasarkan kritik John Rawls, dan dilanjutkan dengan Robert Nozick. Teori utilitarianisme, tidak dapat dipungkiri, lebih menekankan keadilan bersifat kalkulatif, sibuk dengan formula distributif, sehingga bersifat materialis, sebagaimana yang diungkapkan oleh Lebacqs. ${ }^{20}$ Untuk menutupi kekurangan pendekatan Mill tersebut, John Rawls mengusulkan keadilan yang berwawasan marginal. Dengan mengadopsi teori "kontrak sosial" ia menekankan dua prinsip, yaitu kesetaraan (equality) dan kemerdekaan (liberty) demi meminimalisasi tumbal yang berasal dari kelompok minoritas sebagai imbas dari keputusan-keputusan kebijakan yang menguntungkan kelompok mayoritas. Namun, modifikasi tersebut mendapatkan kritik dari Robert Nozick. Dari uraian Lebacqs, Nozick menunjukkan titik lemah teori Rawls yang berpotensi menimbulkan kecemburuan dari pihak-pihak yang bekerja lebih keras yang secara proporsional seharusnya mendapatkan imbalan lebih. Gerak pasar, menurut Nozick, akan dirusak oleh teori Rawls. Oleh karena itu, Nozick berpendapat bahwa keadilan yang merdeka adalah keadilan yang memberikan kesempatan kepada semua orang untuk mendapatkan sesuai usaha kerasnya dalam prinsip peran negara harus diminimalkan, dan kesempatan pertukaran pasar (market exchange) harus dibuka seluasluasnya; dan bagi Nozick, hak tersebut harus dijamin oleh negara. ${ }^{21}$ Namun, keadilan semacam ini hanya menyuburkan praktik kapitalisme, sebagaimana kritik dari Nozick. ${ }^{22}$ Secara spesifik, seandainya hak penggunaan properti dilakukan secara bebas tanpa batas, praktik tersebut justru akan melahirkan ketidakadilan karena berpotensi membatasi hak orang lain; kemerdekaan akan berat sebelah karena ia melahirkan ketidakmerdekaan orang lain. ${ }^{23}$ Argumennya, secara alamiah, yang kuat akan selalu "menjajah" yang lemah. Yang margin, dengan begitu, lagi dan lagi, kehilangan kesempatan untuk memperoleh ruang keadilan.

Nozick mengusulkan peran negara yang lebih dari "minimal" untuk menjamin "redistribusi" keadilan tanpa melukai hak "the greatest good." 24 Dalam hal ini, pendekatan "hak" individu menjadi penting bagi Nozick. Meski demikian, intervensi negara (kekuasaan) untuk menjamin redistribusi keadilan tersebut tidak

\footnotetext{
${ }^{20}$ Ibid., 25-32.

${ }^{21}$ Ibid., 51-58.

22 Ibid., 59.

${ }^{23}$ Ibid., 60.

${ }^{24}$ Ibid., 55
} 
boleh melanggar prinsip kebebasan. Dengan kata lain, hak individu harus dijamin bukan berdasarkan hasil akhir (teleologis), melainkan dengan prinsip "dihormati." Nozick dengan demikian melangkah lebih jauh dari sekadar membangun ruang keadilan secara kalkulatif. Ia menekankan prinsip keadilan yang "tidak ada yang disakiti, dirampas, dilecehkan haknya." ${ }^{25}$ Singkat kata, keadilan bagi Nozick adalah keadilan yang diberikan secara adil.

Lebacqs memberi catatan panjang tentang teori Nozick yang sesungguhnya sangat lemah dalam aplikasi. ${ }^{26}$ Mill, Rawls, dan Nozick, pada kadar tertentu mendapatkan evaluasi dari Lebacqs. Lebacqs mengkritik ketiganya dengan membandingkan dengan pendekatan ajaran sosial Gereja Katolik (social teaching) yang dipaparkan Jose Miranda, serta juga melalui pandangan teologis Protestan Reinhold Niebuhr yang mengusulkan keadilan dari prinsip kasih.

Lebacqs menunjukkan kelemahan dari usulan-usulan para desainer keadilan tersebut dari sudut pandang praksis. Perspektif Katolik memiliki kesamaan dengan dan perbedaan dari konsep keadilan menurut Nozick. Persamaannya adalah keduanya mempertimbangkan hak asasi manusia dan mengusulkan keadilan harus melampaui pertimbangan distribusi dan sosial. ${ }^{27}$ Miranda menekankan kesetaraan relasi sosial sebagai sebuah kesatuan. Misalnya, ia mengusulkan bahwa penggunaan properti pribadi harus dibatasi agar tidak merugikan pihak lain, terutama yang marginal. Untuk membangun ruang keadilan, maka pembatasan harus dilakukan. Dengan demikian, kemerdekaan (freedom) kemudian dibatasi. Ia tidak boleh dimutlakkan demi kepentingan yang lebih besar, yaitu martabat manusia secara kolektif. Pendekatan tersebut sejalan dengan teori Nozick bahwa keadilan harus melibatkan hak partisipatoris dan politis dalam pengaturannya. Oleh sebab itu, Nozick mengusulkan konsep keadilan alkitabiah "mishpat" (bahasa Ibrani untuk kata adil), baik sebagai ukuran hak maupun aksi konkret keadilan. Praktik mendapatkan legitimasi teologis karena ia bersumber pada Allah sebagai Sang Adil. ${ }^{28}$ Oleh karena itu, tindakan adil seseorang dalam partisipasinya menolong yang miskin dan kurang beruntung merupakan tindakan iman yang merupakan respons cinta kepada Allah. ${ }^{29}$

Perbedaan Nozick dengan Miranda terletak pada aplikasinya. Sebagaimana dicatat oleh Lebacqs, kelebihan sekaligus kelemahan dari ajaran sosial Gereja Katolik tersebut adalah, ia terlalu pragmatis dalam memperjuangkan keadilan hingga pada

\footnotetext{
25 Ibid., 58

${ }^{26}$ Ibid., 60-65.

${ }^{27}$ Ibid, 66-68.

${ }^{28}$ Ibid., 72.

${ }^{29}$ Ibid., 74-75.
} 
konsep-konsep distribusi sosialnya. Meski Nozick dan Miranda (pendekatan ajaran sosial Gereja Katolik) menaruh perhatian dalam pendekatan sosial, pendekatan Miranda lebih detail dalam implementasi. Konsep tentang berbagi secara teologis, misalnya, harus dipraktikkan secara nyata: yang kaya harus berbagi kepada yang membutuhkan. ${ }^{30}$ Prinsip struktur sosial kemudian harus berorientasi kepada yang "di bawah" (yang marginal); sebuah industri pertama-tama harus memperhatikan kepentingan pekerja, setelah itu pemilik modal. ${ }^{31}$ Prinsip tentang keadilan yang berbasis pada kepentingan korban ketidakadilan (baik sistem maupun moral) menjadi titik tolak Lebacqs dalam teori-teori yang ia bangun tentang keadilan. Namun sayangnya, sebagai kajian teologis, banyak kritik mengarah ke teori Miranda dan ajaran sosial Gereja Katolik, bahwa ia kehilangan prinsip teologis sebab lebih didominasi oleh pengaruh teori kelas Marx yang bukan tanpa persoalan.

Pendekatan mereka tampak serasi dengan pendekatan Reinhold Niebuhr yang memahami keadilan melalui konsep cinta kasih di mana ia menyatakan bahwa ketidakadilan identik dengan dosa, sementara cinta kasih identik dengan keadilan. ${ }^{32}$ Orang-orang berdosa akan bergerak menuju hidup berkeadilan bila ia mendapatkan anugerah dari Allah dan berorientasi kepada kasih. ${ }^{33}$ Secara pragmatis, Niebuhr mengusulkan bahwa hanya dengan pembagian kekuasaan secara politik yang seimbang, keadilan dapat terwujud. Dengan menunjukkan sejarah ketidakadilan akibat pembagian kekuasaan yang timpang, ia mengusulkan bahwa orangorang Kristen harus segera mengubah praktik hidup, pertama-tama secara politis, sebagai aksi menanggapi rahmat Allah. ${ }^{34}$ Bagi Niebuhr, keadilan tidak pernah sempurna mengingat kasih tidak pernah dapat diwujudkan dengan sempurna baik secara individu, apalagi secara kolektif. ${ }^{35}$ Oleh karena itu, sedapat-dapatnya keadilan harus dipahami memiliki tabiat relatif (diperbarui), dipahami sebagai keadilan dengan kalkulasi kurang-lebih (tidak ketat) terhadap dinamika sosial-politik implementasinya, dan selalu diukur dengan prinsip yang lebih besar dari keadilan, yaitu kasih. ${ }^{36}$ Kasih diterjemahkan oleh Niebuhr dalam ukuran nir-kekerasan, kebebasan-kesetaraan, dan kerelaan berkorban demi orang lain. ${ }^{37}$ Lebih jauh, Niebuhr menetapkan standar moral, bahwa kaum tertindas memiliki hak moral yang lebih tinggi untuk menantang penindasnya ketimbang pihak kuat yang berkewajiban untuk

\footnotetext{
${ }^{30}$ Ibid., 70.

31 Ibid., 70.

32 Ibid., 84-85.

${ }^{33}$ Ibid., 85.

${ }^{34}$ Ibid., 85.

35 Ibid., 85 .

36 Ibid., 86.

${ }^{37}$ Ibid., 86-87.
} 
mempertahankan aturan lewat kekuatan pemaksa. ${ }^{38}$ Dari Niebuhr, jelas bahwa bahwa prinsip teologis (non-kalkulatif) tidak dapat berjalan sendiri, melainkan membutuhkan pendekatan teknis, sosio-politis dengan prinsip-prinsip kasih demi keadilan yang operasional. Alasannya adalah karena kasih tidak dapat diwujudkan secara sempurna; ia hanya bisa didekati untuk disempurnakan.

Jika dalam buku keduanya, Six Theories of Justice, Lebacqs menekankan peran teologis seperti versi Miranda dan Niebuhr, maka di buku pertamanya, Justice in Unjust World, dengan maksud untuk menunjukkan sekat antara adil dan tidak adil, ia mengusulkan untuk menembus sekat tersebut dengan dua cara. Pertama, para pengupaya ruang keadilan harus memiliki kepekaan kepada yang marginal dan menderita. Kedua, keadilan hanya dapat terwujud bila pelaku ketidakadilan dan korban ketidakadilan secara sadar dan dengan kemauan yang sama ingin mengatasi ketidakadilan. ${ }^{39}$ Dari dua cara yang ditempuh tersebut, Lebacqs terlihat lebih menghargai pendekatan teologis yang lebih kualitatif dan holistik ketimbang pendekatan kuantitatif ala utilitarianisme.

Saya yakin bahwa keadilan seharusnya tidak melulu berbasis kalkulasi-kalkulasi sosial, politik, dan ekonomis, melainkan juga teologis. Nilai-nilai spiritual dan religius memiliki pandangan yang lebih holistis ketimbang teknis-matematis dalam mendesain ruang keadilan bagi yang marginal. Tanpa mengklaim bahwa teori tersebut lebih tepat daripada teori lain, melalui testimoni kisah Alkitab berikut, saya ingin menunjukkan bahwa keadilan membutuhkan peran penting setiap anggota masyarakat yang mampu menempatkan diri dalam mewujudkan keadilan bagi yang margin.

\section{Ruang Keadilan dalam Alkitab: \\ Menafsir Keadilan dari Perumpamaan Pekerja di Kebun Anggur (Matius 20:1-16)}

Perumpamaan tentang para pekerja di kebun anggur ini mendemonstrasikan keadilan Allah yang misterius. ${ }^{40}$ Perumpamaan tersebut merupakan testimoni praksis dari konsep keadilan yang melampaui kalkulasi meritokrasi dalam pendekatan filosofis. Merujuk pada Reinhold Niebuhr dalam Justice and Mercy, ungkapan sang pemilik ladang, "Apakah jika aku bermurah hati, engkau [berhak] cemburu?," ingin menempatkan kasih sebagai yang paling utama daripada keadilan proporsional dan keadilan distributif yang biasanya memakai pendekatan kuantitatif. ${ }^{41}$ Jika keadilan dalam

\footnotetext{
${ }^{38}$ Ibid, 87.

${ }^{39}$ Ibid., 122-125.

40 Reinhold Niebuhr, Justice and Mercy (Louisville, KY: Westminster
} John Knox Press, 1974), 63.

${ }^{41}$ Ibid. 
kisah ini begitu misterius, apakah kisah ini dapat menyumbangkan sebuah model keadilan bagi para pejuang keadilan? Mari kita menelusurinya terlebih dahulu.

Menurut tafsir Wilfred Scopes, biasanya orang-orang Galilea kala itu bekerja antara pukul sembilan pagi hingga tiga sore, dan sedikit mengherankan bahwa pekerjaan ini disepakati dan memang selesai jam enam petang. ${ }^{42}$ Kemungkinan besar hal ini dilakukan supaya pekerjaannya selesai pada hari itu juga, pemilik ladang mengantisipasi datangnya hujan yang akan menjatuhkan bulir gandum. ${ }^{43}$ Ada perkiraan bahwa para pekerja yang direkrut dan mulai bekerja pada pagi hari adalah mereka dari golongan Farisi, sedangkan yang direkrut dari hampir petang adalah para pendosa, mantan pemungut cukai yang telah menjadi pengangguran. Dengan kata lain, perekrutan dilakukan atas dasar status agamis. Namun tafsir ini dibantah oleh Craig L. Blomberg dengan mengetengahkan perkiraan lain, yaitu yang direkrut lebih awal merupakan golongan orang mapan secara ekonomi. ${ }^{44}$ Peristiwa ini menunjukkan logika kebiasaan orang menerima pelamar pekerjaan yang memenuhi kriteria produksi: kuat, terampil, dan produktif. Juga, ketika mereka semua diberi upah yang sama, yang bekerja dari jam sembilan pagi bersungut-sungut, cemburu atas apa yang diberikan mandornya kepada pekerja yang hanya bekerja selama satu jam saja. Bagi saya, jika diukur secara produktivitas, dapat dipastikan jasa yang berbanding lurus dengan hasil setiap pekerja jelas berbeda. Dengan demikian, pemberian upah yang sama justru tampak mencederai keadilan, yakni keadilan proporsional. Jadi, bukan karena status sosial-agamisnya, perekrutan dilakukan atas dasar kecakapan bekerja atau berdasarkan prinsip keadilan meritokrasi yang mana dalam perumpamaan ini hendak dianulir karena ada prinsip teologis yang hendak ditekankan. Pertanyaannya kemudian adalah, "Masakan Allah hendak menunjukkan belas kasih dengan mengesampingkan keadilan proporsional?"

Tampaknya, Yesus ingin melimpahkan kasih-Nya kepada yang margin dengan melegitimasi mereka sebagai warga kerajaan Allah. ${ }^{45}$ Kisah ini dapat dipahami sebagai tindakan belas kasih yang melampaui ukuran materi, yang gratis (grace) sekaligus tak ternilai. Cukup mengejutkan, Blomberg menunjukkan, alih-alih ingin memahami betapa belas kasih Allah itu tetap misteri sehingga manusia tak sanggup menyelaminya, ia justru menyebut

42 Wilfred Scopes, The Parables of Jesus and Their Meaning for the Indian Church Today (Diocesan Press, 1977), 101.

${ }^{43}$ Ibid., 101.

${ }^{44}$ Craig L Blomberg, Interpreting the Parables (Leicester: Apollos, 1990), 223.

${ }^{45}$ Daniel J. Harrington, Meeting St. Matthew Today: Understanding the Man, His Mission, and His Message (Chicago: Loyola Press, 2010), 64. 
perumpamaan ini sebagai perumpamaan tentang "majikan sinting" (eccentric employer). ${ }^{46}$

Tafsir ini ternyata mirip dengan tafsir John Dominic Crossan yang menolak penafsiran umum yang menyatakan bahwa pemilik ladang atau majikan tersebut bertindak adil dengan basis kemurah-hatian. Crossan menjuluki majikan tersebut sebagai seorang protagonis dengan dua sifat, yakni pelit dan kapitalis, dengan dua alasan: (1) merekrut pekerja sesedikit mungkin walaupun para pekerja tersebut sudah mengantri dari pagi (yang berdiri saja); (2) menjuluki para pekerja sebagai pemalas (berdiri sepanjang hari). ${ }^{47}$ Tafsir Crossan menyediakan alternatif baru untuk membaca perumpamaan tersebut. Ia berpendapat bahwa perumpamaan haruslah menantang pendengar karena sifatnya pengajaran (ducare: to teach - ducare: to lead). ${ }^{48}$ Sifatnya harus mengedukasi, to lead thought out (berpikir keluar: mencari pengetahuan yang baru), bukan to lead thought in (berpikir ke dalam: berpikir yang sudah diketahui). ${ }^{49}$ Menurut Crossan, pastilah perumpamaan ini berimplikasi lebih jauh, yaitu tentang kemurahhatian dan persoalan keadilan sistemis dan personal. Bagi Crossan, ini bukan tentang kemurah-hatian, sebab dengan demikian karakter perumpamaan sebagai media edukasi gagal..$^{50}$

Walau demikian, Crossan tidak memberikan tafsir definitif selain menyebut karya keadilan personal dan sistemis. Oleh karena itu, saya mempertahankan tafsir tentang kemurah-hatian ala Scopes. Perlu dicatat bahwa pembagian upah dalam perumpamaan tersebut ini tidak melanggar keadilan secara hukum formal. Tidak dijumpai pelanggaran terhadap kesepakatan antara pemilik ladang dan para pekerja.

Pendapat lain, Diedrick Nelson menganggap pola penggajian meritokrasi jelas merugikan pekerja lain. ${ }^{51}$ Jika pekerja yang dari pagi adalah golongan berfinansial stabil yang memiliki kesempatan kerja lebih baik (lebih sering mendapatkan pekerjaan), maka protes menuntut orang lain (pekerja yang jarang mendapatkan pekerjaan, miskin, mungkin juga kaum disabled) mendapatkan gaji lebih rendah merupakan tindakan miskin empati. Nelson menjuluki protes para pekerja tersebut sebagai perilaku iri dan cemburu. Protes untuk diterapkannya praktik penggajian ala meritokrasi justru akan menyebabkan ketimpangan semakin ekstrem. Namun, Nelson kurang setuju dengan pandangan tersebut karena menurutnya, sistem tersebut bukan saja melarang

46 Bloomberg, Interpreting the Parables, 225.

${ }^{47}$ John Dominic Crossan, The Power of Parable: How Fiction by Jesus Became Fiction about Jesus (New York: HarperOne, 2012), 96-97.

48 Ibid., 101.

49 Ibid., 102.

${ }^{50}$ Ibid., 104.

${ }^{51}$ Bloomberg, Interpreting the Parables, 225. 
orang kaya cemburu terhadap pemberian upah kepada si miskin berdasarkan jumlah jam kerja, melainkan sistem ini juga berimplikasi "mewajibkan" orang yang miskinnya tidak ekstrem (masih dalam kategori miskin) untuk menyumbangkan miliknya kepada yang lebih miskin (miskin akut). Tuntutan semacam ini tidak benar, kata Nelson. Namun demikian, keberatan Nelson mendapatkan sanggahan dari B.B. Scott, seperti dikutip Blomberg, bahwa pemberian upah tersebut sama sekali tidak mengambil apapun dari milik si miskin lain. ${ }^{52}$

Kiranya perdebatan keadilan di atas dapat diurai di sini. Jika ukuran keadilan adalah belas kasih Allah, maka seharusnya dibaca sebagai belas kasih yang melampaui keadilan distributif. Contoh lain: Yesus yang ingin menyelamatkan orang-orang berdosa, tidak pernah mengorbankan kelompok lain untuk membayar tebusan. Juga, keadilan yang diperagakan tidak menodai prinsip keadilan secara egalitarian. Penggajian masing-masing satu dinar juga dapat diartikan bahwa anak-anak Allah tidak dibeda-bedakan. Jesus hendak menjelaskan bahwa kasih tidak mengenal strata. Kasih memang tidak sejajar dengan keadilan, melainkan melampauinya. Oleh kerena itu, Niebuhr mengusulkan keadilan sebaiknya selalu berlari ke arah prinsip kasih. ${ }^{53}$ Kasih yang menerobos tipe hidup keseharian, yang dalam tafsir Arland J. Hultgren dimaknai sebagai untypical of ordinary life karena Allah ingin menunjukkan belas kasih yang melampaui perhitungan manusia. ${ }^{54}$ Sekali lagi, keadilan dalam perikop ini memang ganjil. Di satu sisi mereka dibayar dengan jumlah yang sama dengan perbedaan durasi kerja. Di sisi lain, tidak ada pelanggaran hak pengupahan kepada para pekerja. Konsep tersebut dipandang adil karena ada yang mendapatkan haknya sebagai orang yang jarang mendapatkan kesempatan bekerja, miskin, atau mungkin juga penyandang disabilitas.

Michael Green mengusulkan prinsip keadilan yang berbasis belas kasih pertama-tama harus diarahkan bagi yang membutuhkan (the needy). ${ }^{55}$ Dalam kisah ini, mereka "yang [paling] membutuhkan" adalah pekerja yang direkrut pada pukul lima. Mereka diduga adalah orang-orang dengan keterbatasan tertentu-tidak cakap bekerjasehingga jarang direkrut oleh mandor. Para mandor atau pemilik ladang hanya membutuhkan tenaga mereka pada saat-saat tertentu, ketika panen lebih besar dari biasanya (bigger than estimated). Kebiasaan tersebut lumrah. Persoalan ketidakadilan mengemuka

52 Ibid.

${ }^{53}$ Reinhold Niebuhr, Love and Justice: Selections from the Shorter Writings of Reinhold Niebuhr, ed., D. B. Robertson (Louisville, KY: Westminster John Knox Press, 1957), 12-13.

${ }^{54}$ Arland J Hultgren, The Parables of Jesus (Grand Rapids, MI: Wm. B. Eermans Publishing, 2000), 35, 42.

${ }^{55}$ Michael Green, The Parable of Jesus: Picture of Revolution (London: David Wenham Hodder \& Stoughton, 1989), 113-116. 
ketika pemberian upah disamaratakan kepada mereka baik yang bejerih lelah seharian, setengah hari, kurang dari setengah hari, maupun satu jam. Protes terbuka terjadi, para pekerja yang bekerja seharian penuh menuntut keadilan proporsional; perbedaan jam kerja seharusnya mempengaruhi besaran pendapatan.

Green menjelaskan bahwa respons sang pemilik ladang terhadap pekerja yang melakukan aksi protes, tegas namun penuh kasih. Ia memanggil mereka "kawan" untuk menunjukkan ketiadaan rasa benci. Ia menjelaskan secara enigmatis bahwa yang terdahulu menjadi yang terakhir dan yang terakhir akan menjadi yang terdahulu. ${ }^{56}$ Implikasinya bahwa kemurah-hatian yang diberikan kepada pekerja yang baru beberapa jam bekerja, bahkan kepada yang baru sejam bekerja, memang memiliki dampak "upsidedown." ${ }^{57}$ Green menyatakan bahwa Allah dalam kisah ini melakukan sebuah revolusi tingkatan (levelling revolution). "Revolusi tingkatan" secara negatif membawa setiap orang turun tingkat, namun secara positif juga menaikkan tingkat setiap orang lain. Juga, secara positif, kemurahan Allah mempersilakan semua orang bahkan kepada yang datang paling belakangan dalam pekerjaan, mendapatkan gaji yang sama dengan seluruh pekerja.

Tindakan tersebut paralel dengan tindakan Bapa dalam Perumpamaan Anak yang Hilang, yang memberi kesempatan kepada anaknya yang pemboros itu memperoleh kemurahhatiannya. ${ }^{58}$ Baik perumpamaan tentang para pekerja di kebun anggur maupun perumpamaan tentang anak yang hilang mempromosikan prinsip keadilan yang sama dalam pelayanan Yesus, yaitu menyambut orang-orang yang terusir dari masyarakat (the outcast); orang yang tadinya terbuang sekarang masuk dalam hitungan, dalam kesetaraan persahabatan (fellowship), memiliki keanggotaan dan hak secara penuh dalam Kerajaan Allah. ${ }^{59}$ Hal ini menegaskan bahwa tidak satu orang pun yang dinilai terlambat untuk bergabung dalam menyediakan ruang keadilan karena tidak ada yang terlalu buruk untuk dijangkau oleh pelayanan kristiani. Tindakan tersebut mendemonstrasikan dua prinsip keadilan: berpusat pada kasih Allah, dan keadilan tidak melulu bicara tentang kuantitas, melainkan kualitas. Dalam pelayanan Kristen, yang dihitung bukan banyaknya pelayanan dan pengorbanan, melainkan iman kita dalam menerima anugerah Allah. ${ }^{60}$

Kebebasan Allah dalam mendemonstrasikan keadilan tertuang dalam kebebasan sang pemilik ladang dalam memberikan upah kepada para pekerja anggur, sebebas Allah menurunkan hujan kepada mereka yang baik maupun jahat. Tentu saja jika

\footnotetext{
${ }^{56}$ Ibid., 114.

57 Ibid., 114.

${ }^{58}$ Lihat Perumpamaan Anak yang Hilang dalam Lukas 15: 11-32.

${ }^{59}$ Green, The Parable of Jesus, 115.

${ }^{60}$ Ibid., 117.
} 
ditempatkan dalam pemikiran Niebuhr, hukum manusia tentang keadilan akan tampak kabur semua dengan konsep keadilan teologis semacam ini. Kemurahan Allah menjadi gamblang kontras terhadap perangkat [filosofis] terhadap keadilan yang dibangun manusia.

\section{Pengandaian Aplikatif}

Merujuk pada leveling revolution dari Green, saya mengusulkan pengandaian atas perumpamaan ini dalam konteks kita saat ini sebagai berikut. Ucapan Yesus, "yang pertama akan menjadi yang terakhir, dan yang terakhir akan menjadi yang pertama," walau tidak terwakili secara penuh dapat didialogkan dalam pengandaian kontekstual di bawah:
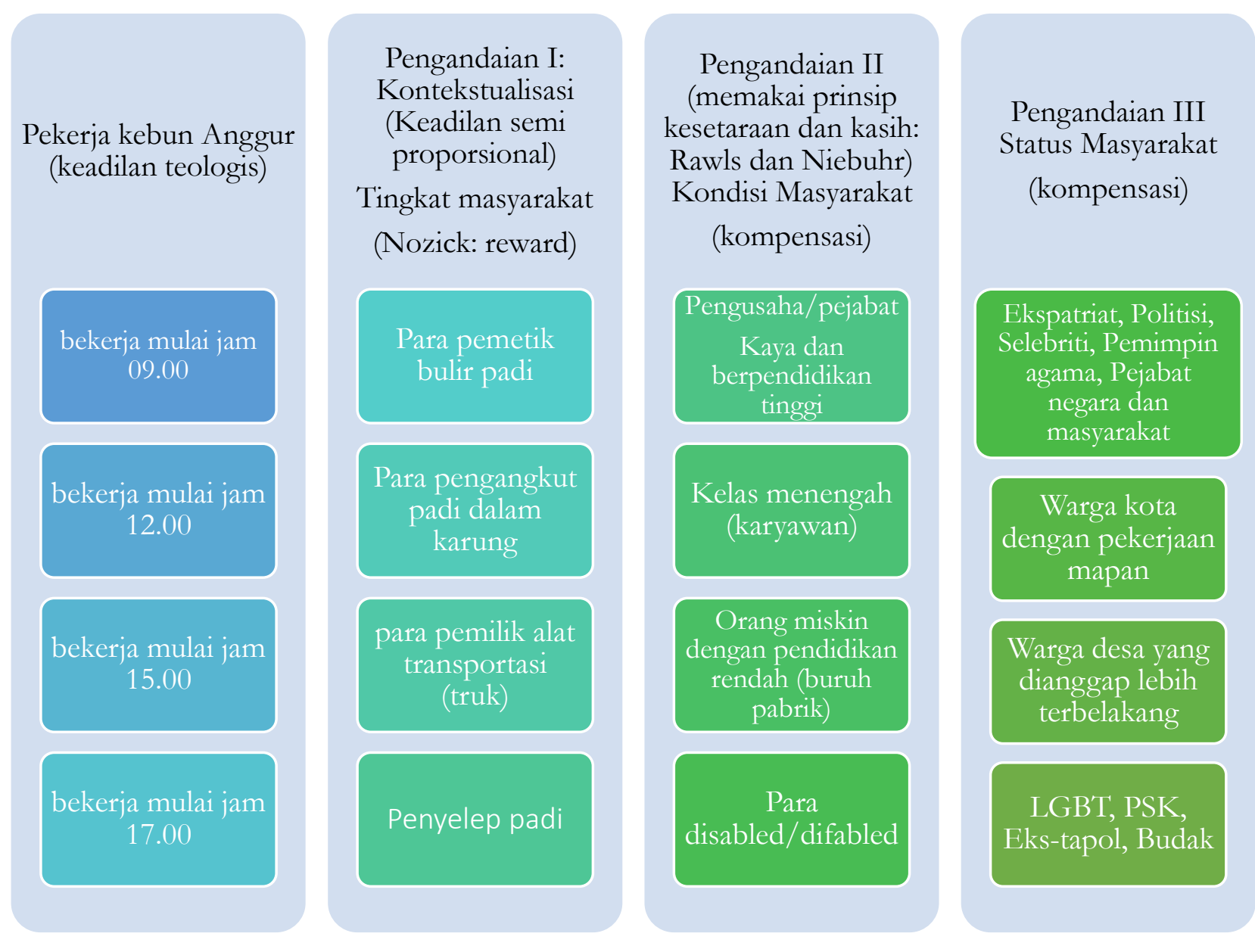

\section{Gambar 1: Skema Pengandaian Keadilan}

Pengandaian I menggambarkan keadilan berbasis proporsional antara beban kerja dan upah; besaran upah yang diberikan tidak dihitung berdasarkan durasi kerja, melainkan atas dasar nilai jasa (merit/reward). Pengandaian II mendemonstrasikan 
bahwa keadilan diberikan merata kepada semua orang tanpa memandang kelas, pekerjaan, dan kemampuan dalam bekerja. Jika dinilai dari kompensasi, seorang kaya yang memberikan kepada negara pajak dalam jumlah besar, seharusnya ia mendapatkan distribusi dari negara lebih besar dari para penyandang difabel apalagi yang tinggal di panti asuhan yang tidak berkontribusi dalam bidang ekonomi sama sekali. Walaupun seandainya kedua kelompok menerima distribusi dari pemerintah dalam jumlah yang sama (dihitung secara kuantitatif), dalam pandangan Niebuhr, kelompok disabled dapat dikategorikan menerima sejumlah subsidi; dalam arti tertentu dapat dikategorikan sebagai "kasih." Nilai dan kemanfaatan inilah yang berbeda. Kasih dalam wujud konkret (kemanfaatan dan nilai) tersebut dapat dimaknai sebagai tindakan "yang terdepan menjadi yang belakangan, dan yang belakangan menjadi yang terdepan."

Selanjutnya, melalui Pengandaian III, hukum dan kebijakan negara sebaiknya memberikan perlindungan masyarakat yang lebih memperhatikan kelompok-kelompok paling bawah/rentan (LGBT PSK, eks-tapol, "budak" yang belum diterima oleh kalangan masyarakat tertentu, penghuni kelas sosial kedua). Dengan demikian, penindasan dalam diskriminasi dalam praktik ekskomunikasi dapat dikurangi. Jika selama ini para penghuni kelas pertama mendapatkan akses hukum, kesempatan kerja, tampil di publik dengan bebas, maka diperlukan upaya bagi kaum marginal untuk tampil bersama mereka tanpa kekakuan psikologis dalam bermasyarakat. Diperlukan jaminan kepada mereka dalam mengakses kesempatan kerja, perlindungan hukum, dan distribusi kekuasaan secara setara. Dalam hal ini, gereja memiliki pekerjaan rumah yang sangat besar ke depan dengan prinsip-prisip teologisnya.

Secara teologis, keadilan Allah justru menganut prinsip ketidaksamaan. Keadilan ilahi juga tidak berdasarkan nilai jasa. Prinsip keadilan semacam ini dapat dijumpai dalam perumpamaan yang Yesus dongengkan kepada para muridnya tentang seorang juragan yang menitipkan talentanya yang mana tiap orang memperoleh pembagian yang tidak sama. Kisah lain, pemberian kasih karunia (kharisma) yang tercatat di dalam I Korintus 12:8-10, yang secara bentuk dan bobot berbeda melambangkan bahwa Allah memang menginginkan setiap orang diperlakukan berbeda. Hal itu konsisten dengan kisah yang direkam dalam Lukas 12:47-48, bahwa dalam kekristenan sesungguhnya ukuran yang dipakai bukan ukuran dunia: tidak ada derajat (degree/gradus) yang memunculkan hierarki manusia. ${ }^{61}$ Anugerah (grace) dalam pemberiannya memang tak mengenal prinsip proporsi, reward, punishment, kuantitatif, dan semacamnya. Ia justru melampaui semua prinsip-prinsip tersebut.

\footnotetext{
${ }^{61}$ Bloomberg, Interpreting the Parables, 222.
} 
Ini merupakan pembalikan (reversal) dari keadilan rasional dalam kajian filosofis. Namun, bukan berarti kajian filosofis lalu batal, melainkan ia digenapi, supaya gagalnya inkonsistensi filosofisseperti yang diutarakan MacIntyre-yang ditinggalkan oleh keadilan dalam sistem masyarakat, kini dapat dipenuhi.

\section{Mengupayakan Ruang Keadilan Teologis}

Salah satu cara memahami bagaimana keadilan dapat diwujudkan melalui pendekatan teologis. Berikut ini kita dapat memanfaatkan pendekatan ruang imajinasi yang dibangun dengan prinsip hospitalitas kekristenan.

Christine D. Pohl menjelaskan pentingnya melestarikan tradisi Kristen untuk membuka pintu dan menyediakan kamar di dalam rumah bagi keluarga, sahabat, dan orang asing. Dalam bukunya Making Room: Recovering Hospitality as a Christian Tradition, ia menjelaskan bahwa praksis hospitalitas merupakan sebuah upaya memberikan ruang keadilan bagi yang marginal. Pengalaman menjadi yatim piatu semenjak usia 13 tahun mengantarkan Pohl melihat relevansi praktik hospitalitas tersebut. Berangkat dari praksis menyediakan kamar, seperti yang dipraktikkan neneknya, Pohl mengajak pembacanya berani untuk membuka ruang hospitalitas di manapun, rumah, gereja, dan di masyarakat, untuk orang lain yang membutuhkan. ${ }^{62}$ Ada pertaruhan risiko (tidak nyaman, bahaya, finansial, dsb.) dalam menerima orang lain itu.

Kendati berisiko, praktik hospitalitas Kristen tersebut relevan bagi hidup masa kini. Pohl mencontohkan bagaimana warga Amerika menolong para gelandangan lokal. ${ }^{63}$ Pengalaman bersama yang margin (with the marginalized) menolong pelaku hospitalitas untuk benar-benar berpikir, merasakan ketakutan seperti orang-orang yang termarginal tersebut. Hal ini sesuai dengan Lebacqs yang mengusulkan pembangunan ruang keadilan harus diawali dari perspektif pengalaman dalam ketidakadilan. Pohl juga menunjukkan betapa ruang keadilan dalam bentuk hospitalitas harus bermula dari dan berpihak kepada yang marginal. ${ }^{64}$ Tindakan hospitalitas tidak hanya memberikan kebutuhan pokok mereka, melainkan hingga ke persoalan rinci untuk bertahan dan menyekolahkan anak-anak mereka. Ada sebuah gerakan masyarakat melalui gereja untuk mempraktikkan secara nyata tradisi hospitalitas tersebut. Ruang bagi yang menderita, yang asing, dan yang lain itu mendesak untuk dibangun. Ruang itu ada di rumah kita. Ruang itu mempertaruhkan praksis hidup kita untuk berubah, bukan kita pusatnya, namun bersama-sama bahu-

${ }^{62}$ Christine D Pohl, Making Room: Recovering Hospitality as a Christian Tradition (Grand Rapids, MI: William B. Eermans Publishing Company, 1999).

${ }^{63}$ Ibid., 85-116.

${ }^{64}$ Ibid., 104. 
membahu meringankan beban orang lain. Tidak ada kalkulasikalkulasi untung rugi lagi. Bahkan, tidak jarang penyedia ruang hospitalitas kuatir akan ruangan untuknya sendiri. Pohl menyebut dua hal yang menjadi pertaruhan, keterbatasan sumber daya dan perbedaan identitas dengan orang asing yang kita tolong.

\section{Letty Russel: Memperluas Ruang Keadilan}

Mirip dengan, namun berbeda dari, usulan Pohl, Letty Russell mengusulkan setiap orang (Kristen) untuk memperluas ruang/lingkaran keadilan. Russell menyebut orang-orang yang termarginal dalam terminologi, "in but still out" yang tercermin dalam komunitas gereja Presbitarian di Amerika, komunitas Russel berjemaat. ${ }^{65}$ Terminologi tersebut ingin menjelaskan bahwa ada banyak orang yang berada dalam lingkaran pergaulan, "dekat di mata" yang sesungguhnya masih mengalami diskriminasi, karena mereka "jauh di hati." Lingkaran keadilan tersebut menggambarkan ruang imaginasi di mana tiap-tiap orang atau kelompok menguasai pusat kekuasaan, ekonomi, bahkan pergaulan sehingga tercipta dominasi kepada yang di pinggir atau bahkan di luar lingkaran. Russell mengakui dirinya, sebagai seorang lesbian yang dapat dipahami sebagai mewakili kelompok perempuan dan LGBT, mengalami diskriminasi tersebut. Ia teralienisasi dari gereja karena identitas orientasi seksualnya.

Diskriminasi tersebut telah mengantarkan Russell untuk mengusulkan teologi keramahtamahan yang berkeadilan atau Just Hospitality yang valid bagi konteks universal di mana gereja masih menghakimi orang-orang tertentu di dalamnya, di dalam masyarakat yang mengucilkan orang berbeda agama maupun etnis. Prinsip "memperluas ruang keadilan" seolah ingin menunjukkan bahwa tidak adil jika orang-orang yang tinggal di pusat lingkaran (orang penting di gereja, orang-orang kaya di lingkungan, para pemilik jabatan dalam negara, mereka yang berlimpahan cinta) mengabaikan mereka yang di pinggir, yang marginal, yang tidak berdaya. Kekristenan tidak pernah mengizinkan praktik dominasi semacam ini. Para outsider, ajak Russell, harus dirangkul supaya masuk dalam lingkaran yang merupakan ruang setara bagi semua orang. Namun demikian, cara yang paling relevan bukanlah menarik mereka ke dalam, melainkan memperluas lingkaran/ruang keadilan sebagai rumah keramahtamahan. ${ }^{66}$

Seseorang yang berada di pusat (center) hendaknya menghargai orang-orang yang berada di pinggiran; ia yang selalu tinggal di pinggir harus dipertimbangkan sebagai saudara, sebab

${ }^{65}$ Letty M Russell, Just Hospitality: God's Welcome in a World of Difference, eds., J Shannon-Clarkson and Kate M Ott, 1st ed. (Louisville, KY: Westminster John Knox Press, 2009), 4-6, 14-15.

${ }^{66}$ Ibid., 45-47. 
mereka memang saudara, arti lain dari the others. Bukankah sudah wajar setiap orang dihargai martabatnya dalam persekutuan kristiani? Bagi Russell, keramahtamahan adalah penyambutan yang hangat kepada mereka yang berbeda dengan segala identitasnya; semua berhak terlibat dalam tindakan Allah mewujudkan keadilan dan pemulihan bagi krisis dunia, salah satunya krisis keamanan karena takut terhadap sesama. Ia mengatakan: ${ }^{67}$

Hospitalitas adalah sebuah praktik tentang sambutan Allah yang menjangkau perbedaan untuk berpartisipasi dalam tindakan Allah yang menghadirkan keadilan dan berkarakter menyembuhkan di dalam krisis dunia dan rasa takut dari mereka yang kita sebut sang liyan (other).

Russell menegaskan pentingnya hospitalitas dalam bentuk "ruang imajinasi" bagi misi Kristen, sebuah ruang tanpa palang/sekat (remove all bars) pemisah perbedaan. ${ }^{68}$ Pertama-tama membaginya dalam ruang pinggir dan pusat, atau di dalam ruangan dan di luar ruangan. Pembagian tersebut mengkatalisasi praktik ketidakadilan. Ruang pusat (di dalam ruangan) dihuni mereka yang merasa memiliki gereja, dan ruang pinggir (di luar ruangan) dihuni mereka yang dianggap berdosa. Dalam keprihatinan tersebut, Russell mengusulkan praktik hospitalitas untuk mengembalikan yang di pinggir atau yang di luar ruangan, masuk dan tidak dibedakan dari yang di pusat. Russell mengkritik penatalayanan kristiani yang seringkali luput memberi perhatian kasih kepada mereka yang hadir dalam kebaktian di gereja, mengikuti kegiatan kemasyarakatan, namun tetap merasa kesepian akibat diskriminasi. Masih terlalu banyak orang yang di dalam namun masih di luar (in but still out), jelas Russell. ${ }^{69}$ Lingkaran kasih kita perlu diperluas, bahkan kalau perlu seluas-luasnya, menjangkau sebanyakbanyaknya. ${ }^{70}$ Pelayanan gereja dan orang Kristen, sebagaimana keberpihakan Allah kepada mereka yang menderita, harus diarahkan kepada para janda, yatim, dan yang terasing, tanpa membuat hierarki baru di mana ada yang ditolong dan yang menolong-mereka adalah partner setara dalam mewujudkan kesejahteraan. ${ }^{71}$

Untuk mewujudkan keadilan dan mengurangi potensi ketidakadilan, maka pertama-tama perlu adanya distribusi kekuasaan dan sumber daya yang adil dalam komunitas sehingga tidak muncul pihak-pihak yang arogan di satu sisi, dan tertindas di sisi lain. Kedua, kita perlu memberi perhatian kepada yang kurang

\footnotetext{
${ }^{67}$ Ibid., 53.

${ }^{68}$ Ibid., 53.

${ }^{69}$ Ibid., 4.

70 Ibid., 60.

${ }^{71}$ Ibid., 49.
} 
diperhitungkan dalam komunitas. Ketiga, dengan tindakan itu, kita pantas bersukacita karena sesungguhnya kita sedang menggenapi janji Allah. ${ }^{72}$ Sebuah komunitas yang setara harus dibangun berdasarkan prinsip setara walau tak sama, dalam perbedaan bukan kesamaan, bukan ini atau itu (neither-nor), melainkan boleh ini atau boleh itu (either-or); bukan berdasarkan salah benar, menang-kalah, melainkan dibangun dalam keterbukaan sebagaimana Kristus memasuki dunia; dunia sebagai Kerajaan Allah. ${ }^{73}$

\section{Amos Yong: Memindahkan Pusat Keadilan (Stranger Centered)}

Melalui cara Allah memasuki dunia ini, Amos Yong dan Russell sama-sama menawarkan keramahtamahan ilahi. Yong melalui bukunya Hospitality and the Others menyerukan supaya orang asing (the strangers) dirangkul sehingga mereka tidak asing lagi. ${ }^{74}$ Perbedaannya, jika Russell menyerukan supaya lingkaran keramahtamahan diperluas, Yong menyarankan supaya pelayanan Kristiani berpusat pada orang asing itu (stranger-centered). ${ }^{75}$ Menimbang kembali prinsip keadilan dari kisah perumpamaan para pekerja di kebung anggur bahwa, mereka yang digolongkan "yang terbelakang," harus dijadikan "yang terdepan," Yong menandaskan. Persis dengan memindahkan titik sasaran dari sebuah tindakan keadilan. Ada yang dipindahkan: yang tadinya terbelakang dikedepankan-yang tadinya di pinggir di-pusat-kan, yang asing direngkuh dalam persaudaraan. Dalam hal ini, Yong mengusulkan supaya orang Kristen-sebagaimana Allah telah melakukannya-mengunjungi mereka yang asing, menjadikan mereka menjadi sasaran utama dari tindakan kasih kita dalam bahasa mereka; memulihkan martabat orang asing.

72 Ibid., 43.

${ }^{73}$ Ibid., 65.

${ }^{74}$ Amos Yong, Hospitality and the Other: Pentecost, Christian Practices, and the Neighbor (Maryknoll, NY: Orbis Books, 2008), 153-156.

75 Ibid., 132. 


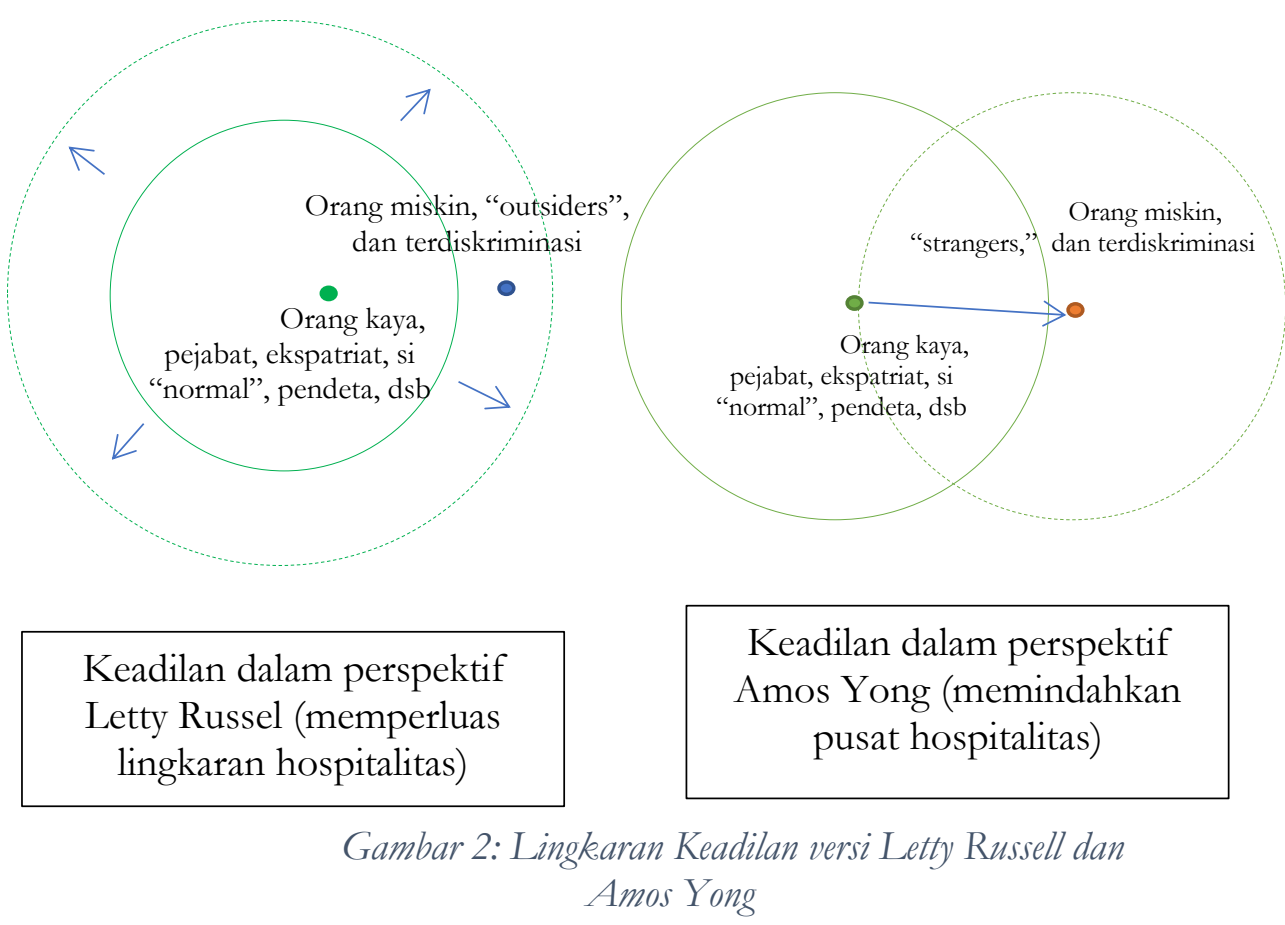

Jika lingkaran keadilan dalam prinsip Russell diperluas, lingkaran keadilan ala Yong digeser posisi titik pusatnya. Russell memiliki kelebihan bahwa baik yang dipinggir maupun yang di pusat lingkaran keadilan, akhirnya sama-sama tinggal dalam lingkaran keadilan — setara dan berjuang bersama. Sementara itu, lingkaran keadilan ala Yong mendorong orang-orang yang dianggap lebih kuat, lebih mampu, untuk menolong mereka yang terpinggirkan, yang kurang beruntung dalam mengakses sumber sarana kehidupan yang holistik: ekonomi, hukum, perlakuan orang lain dalam lingkungan.

\section{Miroslav Volf: Merangkul Sang Lain (The Other)}

Volf mengungkapkan tiga kemungkinan cara untuk menemukan keadilan. Pertama, berangkat dari penegasan universal bahwa keadilan itu "satu" (bersifat menyatukan). Kedua, keadilan mestinya sepakat dengan keinginan untuk merangkul pihak lain dan bahwa keadilan itu sendiri akan menjadi tidak adil sepanjang tidak disambut kedua pihak yang saling merangkul (mutual embrace). Ketiga, melalui pendekatan teks Alkitab, ia merefleksikan keadilan versi peristiwa Pentakosta vis-à-vis latar belakang ketidakadilan di Babel dalam upaya pencarian keadilan pada/bagi masyarakat yang plural dan rentan permusuhan. ${ }^{76}$ Keterbukaan menjadi kunci bagi keadilan yang selama ini buntu karena polarisasi masyarakat dengan kepentingan, identitas, perspektif, dan seterusnya. Volf bertutur

\footnotetext{
76 Volf, Exclusion and Embrace, 226-230.
} 
bahwa keadilan harus diupayakan dua pihak yang bersedia berubah dan diubahkan: ${ }^{77}$

Cara timbal balik: kita memang memiliki pendirian sendiri, namun sekaligus dapat belajar dari tradisi lain. Oleh karena itu, mari kita perluas cara pandang kita dengan mengizinkan suara-suara dan sudut pandang dari orang lain, terutama dengan mereka yang terlibat konflik dengan kita; gemakan dalam diri kita, dengan mengizinkan mereka untuk menolong kita dalam memandang mereka, sebagaimana kita sendiri, dari sudut pandang mereka; dan jika dibutuhkan, ubahlah cara pandang kita sebagaimana kita menyelami bagaimana mereka memandang kita.

Volf memang menawarkan sebuah keadilan yang dilandasi keterbukaan radikal yang mensyaratkan kedua pihak yang bertikai dalam sengketa keadilan untuk saling merangkul, memperbaiki diri, dan men[di]damaikan. ${ }^{78}$ Kedua belah pihak harus mampu menciptakan ruang bagi mereka berdua untuk bukan hanya berubah dalam pandangan tentang keadilan, namun juga menyadari risiko terluka demi perdamaian di antara mereka. Luka-luka ketika konflik harus disikapi dengan prinsip pengampunan. Kepolosan atau kemurnian untuk bersedia merangkul pihak lain pertama-tama harus dilakukan dengan melepaskan status korban dan pelaku kekerasan. Keduanya adalah korban dari praktik ketidakadilan yang mungkin saja sistemik (komando militer) atau dalam ketidaksadaran (mengimitasi pengalaman). Dalam situasi konflik, menginginkan keadilan saja tidak cukup untuk mewujudkan keadilan; dibutuhkan tangan yang benar-benar siap memeluk orang lain. ${ }^{79}$ Volf menulis, "Tidak akan pernah ada keadilan tanpa kesediaan untuk merangkul sang liyan, tidak akan pernah ada rangkulan yang murni dan abadi tanpa keadilan." $\$ 0$

Dalam kesimpulan terakhir dalam bukunya Justice in Unjust World, Lebacqs menulis bahwa dalam keadaan manusia yang terbelah ke dalam adil dan tidak adil, Allah mendekati kita dan bicara kepada kita melalui kelemahan kita (brokenness). ${ }^{81}$ Oleh karena itu, ruang keadilan memang harus didesain pertama-tama dengan wawasan atau kepekaan terhadap fakta ketidakadilan. Kemudian, dibutuhkan belas kasih untuk mempraktikkan hospitalitas yang setulus-tulusnya dengan mengingat keadilan Allah (teologis) dalam merespons ketidakadilan. ${ }^{82}$

77 Ibid., 213.

78 Ibid.

${ }^{79}$ Ibid., 216.

80 Ibid., 216.

${ }^{81}$ Lebacqs, Justice in an Unjust World, 141, 148.

${ }^{82}$ Russell, Just Hospitality, 149. 


\section{Kesimpulan: \\ Keadilan adalah Cita-cita Keramahtamahan}

Dalam tanggung jawab menyikapi peristiwa ketidakadilan terhadap mereka yang ter/dimarginalisasi karena identitas ras, gender, usia, dan agama, membangun ruang keadilan sebagai praktik keramahtamahan (hospitalitas) menjadi krusial. Keramahtamahan Kristen mampu menutup keterbatasan pendekatan filosofis yang terjebak pada kecenderungan perhitungan teknis. Keramahtamahan adalah hadiah cinta kasih kepada mereka sebagai umat Allah; memberi adalah hakikat dari karunia Allah. ${ }^{83}$ Melalui pendekatan teologis kemurahhatian, ruang keadilan setidaknya tidak dibangun pertama-tama berdasarkan desain spekulatif yang cenderung top-down, melainkan dimulai dari perspektif korban ketidakadilan, yang terdahulu menjadi yang terakhir dan yang terakhir akan menjadi yang terdahulu (upside down), berorientasi kepada kesetaraan semua orang, melampaui perdebatan deontologis-teleologis (proses-tujuan).

Dari penelusuran di atas, saya meyakini bahwa perdebatanperdebatan tentang definisi keadilan sesungguhnya tidak lebih dibutuhkan ketimbang praktik menciptakan keadilan dalam perspektif Kristiani yang menjunjung kasih, salah satunya melalui tindakan hospitalitas. Saya sepakat dengan Lebacqs dalam ketegasan pendiriannya dalam mengupayakan ruang keadilan sebagaimana ia ungkapkan dalam "Implications for theory of justice," bahwa teori-teori tentang keadilan selalu kuat dalam satu sisi dan lemah di sisi lain. Oleh karena itu, ia mengusulkan setidaknya empat pendekatan cara membangun ruang keadilan: (1) dengan pemahaman Alkitab tentang kebenaran (righteousness) tentang relasi yang benar (right relationship) demi kemurahan hati sebagai wujud kasih; (2) mewujudkan keadilan adalah sebuah tanggung jawab dan tugas, bukan hak; (3) tidak boleh ada yang mendominasi dan didominasi sebab dominasi biasanya melahirkan pelanggaran relasi yang benar sebagai wujud perjanjian dengan Allah, yaitu bahwa setiap orang dihargai dalam keadilan Allah; (4) bagi para korban ketidakadilan dan pelaku ketidakadilan, keadilan harus dibangun dengan kesadaran bersama untuk memperbaiki situasi ketidakadilan, yaitu berorientasi pada pembebasan yang ditindas; (5) setiap teori, pendekatan, dan pelaku dari proyek mewujudkan ruang keadilan harus bersedia selalu melakukan koreksi diri, analisis terhadap teori dan aksi dalam upaya mewujudkan keadilan. ${ }^{84}$ Dari lima pendekatan itu, ruang yang

${ }^{83}$ Ibid., 70.

${ }^{84}$ Karen Lebacqz, "Implications for a Theory of Justice," in From Christ to the World Introductory Readings in Christian Ethics, eds., Wayne G Boulton, Thomas D Kennedy, and Allen Verhey (Grand Rapids, MI: W.B. Eerdmans, 1994), 256-257. 
paling valid dibangun adalah ruang hospitalitas dengan kriteria kasih, murah hati, merangkul liyan, dan berorientasi kepada mereka yang dipinggirkan.

Lebih jauh, teori-teori tentang keadilan seharusnya bukan yang pertama didiskusikan atau diusulkan, melainkan kita perlu memahami situasi dan korban ketidakadilan yang relatif (bersesuaian dengan konteks ketidakadilan). Kalkulasi-kalkulasi dan istilah-istilah filsafat perlu "tahu diri" sebelum mengusulkan, bahkan mengklaim kebenaran teori mereka. Keadilan bukan melulu soal kalkulasi dan teori, melainkan juga, yang lebih penting, adalah soal aksi dan tindakan murah hati sebagai perwujudan niat membangun ruang keadilan bagi yang berada di margin. Selain bahwa tindakan kasih dalam keadilan tidak boleh terjebak dan mandek dalam diskusi, keadilan sebagai bagian dari misi Kristen tidak seharusnya diidentikkan dengan jumlah atau kuantitas yang menyebabkan keadilan menjadi parsial. Dengan kata lain, keadilan tidak boleh memihak mereka yang mayoritas, yang kuat seperti klaim Trasymachos, dan yang memiliki suara paling keras dalam mengambil kebijakan menyangkut distribusi kehidupan manusia: ekonomi, keadilan hukum, dan kebebasan sosial. Keadilan filosofis dalam tema utilitarianisme, kesetaraan, dan tidak bertumbal, bagi saya, tidak akan bermanfaat jika secara moralis dan teologis, misalnya dengan menekankan kasih, tidak diterjemahkan secara nyata.

Melalui diskusi dalam artikel ini, saya ingin menegaskan bahwa di dalam ruang hidup kita bersama, selalu ada yang menderita karena hidup dalam ruang ketidakadilan. Kepekaan kita terhadap fakta ini merupakan keniscayaan bagi kita untuk mengupayakan ruang-ruang keadilan. Jika tidak, maka ruang keadilan yang dibangun bagi mereka yang di(ter)maginalkan tidak pernah dapat terwujud. Sekali lagi, keadilan tidak pernah dapat diwujudkan melalui semata-mata pendekatan teknis dan kalkulatif karena keadilan tidak mengenal angka. Jika ada satu orang saja yang menderita, dipinggirkan, dihalau dari komunitas karena mereka berbeda, lemah, dan tidak berdaya berhadapan dengan status quo dalam sistem masyarakat, berarti ruang keadilan itu semu belaka, belum dibangun, atau bahkan tidak pernah ada niat untuk membangunnya. Oleh karena itu, prinsip kasih, kemurah-hatian, belas kasih, dan bela-rasa kepada yang lemah, sebagai buah dari teologi Kristen, kiranya dapat dilihat kembali sebagai prinsip yang paling relevan dalam mengupayakan ruang-ruang keadilan di tengah-tengah rumitnya problem ketidakadilan. 


\section{Tentang Penulis}

Danang Kurniawan menyelesaikan S1 dalam bidang Teologi di Sekolah Tinggi Teologi Jakarta. Ia mengambil program International Peacemaking Program di Hartford Seminary, lalu meneruskan program master di sekolah yang sama dan lulus tahun 2019. Bidang minatnya adalah etika, public/political theology, dan interreligious studies.

\section{Daftar Pustaka}

Blomberg, Craig L. Interpreting the Parables. Leicester: Apollos, 1990.

Crossan, John Dominic. The Power of Parable: How Fiction by Jesus Became Fiction about Jesus. New York: HarperOne, 2012.

D'Costa, Gavin. Theology in the Public Square: Church, Academy, and Nation. Theology in the Public Square: Church, Academy, and Nation. Malden, MA: Blackwell Publishing, 2008.

Graver, Margaret. "Epictetus.” Stanford Encyclopedia of Philosophy, 2017. https://plato.stanford.edu/entries/epictetus/.

Green, Michael. The Parable of Jesus: Picture of Revolution. London: David Wenham Hodder \& Stoughton, 1989.

Harrington, Daniel J. Meeting St. Matthew Today: Understanding the Man, His Mission, and His Message. Chicago: Loyola Press, 2010.

Hultgren, Arland J. The Parables of Jesus. Grand Rapids, MI: Wm. B. Eerdmans Publishing, 2000.

Lebacqz, Karen. "Implications for a Theory of Justice.” In From Christ to the World Introductory Readings in Christian Ethics.Eds., Wayne G Boulton, Thomas D Kennedy, and Allen Verhey. Grand Rapids, MI: W.B. Eerdmans, 1994.

- Justice in an Unjust World: Foundations for a Christian Approach to Justice. Minneapolis, MN: Fortress Press, 2007.

- Six Theories of Justice: Perspectives from Philosophical and Theological Ethics. Minneapolis, MN: Augsburg Publishing House, 1986.

Macintyre, Alasdair C. Whose Justice? Which Rationality? Notre Dame, IN: University of Notre Dame Press, 1988.

Magnis-Suseno, Franz. 13 Tokoh Etika Abad Ke 20. Yogyakarta: Kanisius, 2000.

Niebuhr, Reinhold. Justice and Mercy. Louisville, KY: Westminster John Knox Press, 1974.

- Love and Justice: Selections from the Shorter Writings of Reinhold Niebubr. Ed., D. B. Robertson. Louisville, KY: Westminster John Knox Press, 1957.

Pohl, Christine D. Making Room: Recovering Hospitality as a Christian Tradition. Grand Rapids: William B. Eermans Publishing 
Company, 1999.

Russell, Letty M. Just Hospitality: God's Welcome in a World of

Difference. Eds., J Shannon-Clarkson and Kate M Ott. 1st ed. Louisville, KY: Westminster John Knox Press, 2009.

Scopes, Wilfred. The Parables of Jesus and Their Meaning for the Indian Church Today. Diocesan Press, 1977.

Vasko, Elisabeth T. Beyond Apathy: A Theology for Bystanders.

Minneapolis, MN: Fortress Press, 2015.

Volf, Miroslav. Exclusion and Embrace: A Theological Exploration of Identity, Otherness, and Reconciliation. Nashville, TN: Abingdon Press, 1996.

Yong, Amos. Hospitality and the Other: Pentecost, Christian Practices, and the Neighbor. Maryknoll, NY: Orbis Books, 2008. 